\title{
Perubahan Strong Ion Difference Pasca Resusitasi Cairan antara Ringer Laktat dan Normal Salin pada Anak dengan Syok
}

\author{
Yuli Amuntiarini, ${ }^{*}$ Silvia Triratna, ${ }^{*}$ Irfanuddin** \\ ${ }^{*}$ Departemen Kesehatan Anak Fakultas, ${ }^{* *}$ Unit Penelitian Kedokteran Kesehatan Kedokteran Universitas Sriwijaya/RS Moh. \\ Hoesin, Palembang
}

\begin{abstract}
Latar belakang. Pemberian cairan resusitasi pada syok akan memengaruhi status asam basa tubuh melalui pengaruhnya terhadap strong ion difference (SID) berdasarkan teori Stewart. Normal salin (NS) dan ringer laktat sering digunakan sebagai cairan resusitasi namun terdapat kekhawatiran bahwa penggunaan NS dapat menyebabkan asidosis hiperkloremik dan masalah ini belum banyak diteliti pada anak.

Tujuan. Membandingkan perubahan SID dan $\mathrm{pH}$ plasma setelah pemberian cairan RL dan NS pada syok.

Metode. Dilakukan uji klinik terbuka acak terkontrol di UPIA RSMH bulan Juli 2014 sampai Maret 2015. Randomisasi blok dilakukan pada 44 subjek penelitian rentang usia 2 bulan sampai 14 tahun.

Hasil. Terdapat 23 subjek pada kelompok RL dan 21 pada kelompok NS. Pada kelompok RL, rerata SID dan pH setelah resusitasi tidak mengalami perubahan bermakna (SID 32,96 $\pm 5,26$ menjadi 32,32 $\pm 6,34 \mathrm{mEq} / \mathrm{L}, \mathrm{p}=0,089 ; \mathrm{pH} 7,40$ menjadi 7,42 dengan

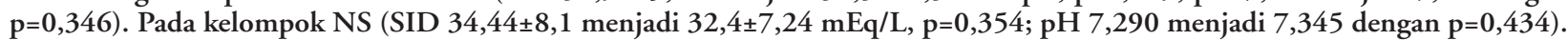
Antara kelompok RL dan NS, tidak ditemukan perbedaan bermakna dalam rerata selisih SID ( $\triangle$ SID RL $-1,22 \mathrm{mEq} / \mathrm{L}$ dan NS $-1,97 \mathrm{mEq} / \mathrm{L}$ dengan $\mathrm{p}=0,177)$ dan $\mathrm{pH}(\Delta \mathrm{pH}$ RL $0,013 \pm 0,088$ dan NS $0,032 \pm 0,11$ dengan $\mathrm{p}=0,534)$. Ditemukan penurunan bermakna kadar kalium pada kelompok NS setelah resusitasi $(4,32 \pm 1,05$ menjadi 3,73 $\pm 1,06 \mathrm{mEq} / \mathrm{L}, \mathrm{p}=0,032)$.

Kesimpulan. Resusitasi cairan dengan RL dan NS memberikan perubahan SID dan $\mathrm{pH}$ yang tidak berbeda pada kasus syok anak di unit perawatan intensif anak. Sari Pediatri 2015;17(3):222-8.
\end{abstract}

Kata kunci: strong ion difference, syok, ringer laktat, normal salin

\section{Changes in Strong Ion Difference after Fluid Resuscitation with Ringer Lactate and Normal Saline in Children with Shock}

Yuli Amuntiarini, ${ }^{*}$ Silvia Triratna,* Irfanuddin**

Background. Administration of resuscitation fluids during shock can alter acid-base balance by their effects on strong ion difference (SID) as explained by Stewart. Normal saline (NS) and ringer lactate (RL) solutions are frequently used as resuscitation fluids, however there are concerns that the use of NS may cause hyperchloremic acidosis. Studies on this issue are scarce in the pediatric population.

Objective. To compare changes in plasma SID and $\mathrm{pH}$ after administration of ringer lactate (RL) and normal saline (NS) during shock.

Methods. An open label randomized clinical trial was performed in the Mohammad Hoesin Hospital Pediatric Emergency Unit from July 2014 to March 2015. Block randomization was done for the allocation of 44 children.

Results. Twenty three children were assigned to RL group while 21 to NS group. In the RL group, there were no significant changes on SID $(32.96 \pm 5.26$ to $32.32 \pm 6.34 \mathrm{meq} / \mathrm{l}, \mathrm{p}=0.089)$ or $\mathrm{pH}(7.40$ to $7.42, \mathrm{p}=0.346)$ after resuscitation. In the NS group, similar findings were observed for SID (34.44 \pm 8.1 to $32.4 \pm 7.24 \mathrm{meq} / \mathrm{l}, \mathrm{p}=0.354)$ and $\mathrm{pH}(7.290$ to $7.345, \mathrm{p}=0.434)$. Comparison between changes of SID and $\mathrm{pH}$ between RL and NS revealed no significant differences ( $\triangle$ SID for RL $-1.22 \mathrm{meq} / \mathrm{l}$ and NS -1.97 $\mathrm{meq} / \mathrm{l}, \mathrm{p}=0.177)(\Delta \mathrm{pH}$ for RL $0.013 \pm 0.088$ and $\mathrm{NS} 0.032 \pm 0.11, \mathrm{p}=0.534)$. A significant decrease of potassium level was observed in the NS group post resuscitation $(4.32 \pm 1.05$ to $3.73 \pm 1.06 \mathrm{meq} / \mathrm{l}, \mathrm{p}=0.032)$.

Conclusion. Fluid resuscitation using ringer lactate or normal saline for shock in children does not produce a significantly different changes in SID and pH. Sari Pediatri 2015;17(3):222-8.

Keywords: strong ion difference, shock, ringer lactate, normal saline

Alamat korespondensi: Dr. Yuli Amuntiarini. Departemen Kesehatan Anak, Fakultas Kedokteran Universitas Sriwijaya, Jl. Jenderal Sudirman KM 3,5 Palembang, Indonesia. Email: amuntai@yahoo.com 
$\mathrm{P}$ emberian cairan resusitasi diperlukan untuk meningkatkan volume intravaskular dan merupakan intervensi yang penting dan paling sering digunakan pada syok. ${ }^{1,2}$ Tata laksana yang cepat dapat memberikan perbaikan yang signifikan, sebaliknya keterlambatan dapat meningkatkan mortalitas. ${ }^{3}$ Pada anak yang mengalami syok, cairan resusitasi yang digunakan di antaranya normal salin (NS) dan ringer laktat (RL). Di Amerika, NS merupakan cairan kristaloid yang paling sering digunakan sebagai cairan resusitasi. Normal salin mengandung natrium dan klorida dengan konsentrasi yang setara sehingga bersifat isotonik terhadap cairan ekstraselular. Cairan RL juga kurang lebih setara dengan cairan ekstraselular sehingga disebut sebagai cairan fisiologis. Bagaimanapun juga, keduanya tidak ada yang memiliki komposisi yang persis sama dengan plasma. $^{2}$

Pemberian cairan resusitasi dapat menyebabkan terjadinya dilusi plasma dan perubahan komponen plasma mendekati komponen cairan yang diberikan. Stewart dalam Darwis $\mathrm{dkk}^{4}$ dan Morgan $\mathrm{dkk}^{5}$ memperkenalkan suatu konsep bahwa pemberian cairan akan memengaruhi status asam basa tubuh melalui pengaruhnya terhadap strong ion difference (SID) atau perbedaan ion kuat di dalam plasma. Strong ion difference didapatkan dari perbedaan antara muatan positif dan negatif elektrolit di dalam plasma yang kemudian akan meningkatkan ion hidrogen bebas untuk mempertahankan netralitas elektrik. ${ }^{6}$

Konsep Stewart ini memberikan pemahaman tentang fenomena asam basa yang akan terjadi pada pemberian cairan intravena tersebut. Ion yang terutama memengaruhi SID adalah natrium $\left(\mathrm{Na}^{+}\right)$dan klorida $(\mathrm{Cl})$. Perhitungan SID didapat dari konsentrasi ion kuat terukur dalam plasma melalui rumus $[S I D]=$ $\left[\mathrm{Na}^{+}\right]+\left[\mathrm{K}^{+}\right]+\left[\mathrm{Ca}^{++}\right]-[\mathrm{Cl}-]$. Nilai normal SID dalam plasma adalah $42 \mathrm{mEq} / \mathrm{L}$. Peningkatan kation total akan menurunkan konsentrasi $\mathrm{H}^{+}$dan meningkatkan $\mathrm{pH}$ (alkalosis), sebaliknya peningkatan jumlah anion total akan menurunkan $\mathrm{pH}$ (asidosis). ${ }^{4,5}$

Pemberian NS dalam volume yang besar dapat menyebabkan asidosis metabolik dengan meningkatkan konsentrasi relatif klorida terhadap konsentrasi sodium plasma sehingga terjadi penurunan SID dan $\mathrm{pH}$. Kondisi ini disebut sebagai asidosis hiperkloremia. ${ }^{6}$ Pada RL, penambahan ion laktat membutuhkan penurunan konsentrasi klorida untuk mempertahankan netralitas elektrik sehingga konsentrasi klorida RL lebih rendah dari NS.7,8 Ion laktat pada RL juga menyebabkan efek alkalinisasi sehingga ringer laktat merupakan base corrector. ${ }^{9}$ Penelitian Dyah ${ }^{10}$ menunjukkan adanya peningkatan klorida dan perubahan SID yang bermakna pada pemberian normal salin dibandingkan dengan RL pada volume $20 \mathrm{cc} / \mathrm{kgbb}$, tetapi tidak menyebabkan perubahan $\mathrm{pH}$ yang bermakna.

Konsekuensi klinis asidosis hiperkloremia yang disebabkan pemberian cairan ini masih belum sepenuhnya dipahami. Temuan klinis dan laboratorium terbukti sangat kompleks dan tidak konsisten sehingga menimbulkan banyak perbedaan pendapat. ${ }^{11}$ Tujuan penelitian ini adalah untuk mengetahui perubahan SID dan $\mathrm{pH}$ plasma setelah pemberian cairan ringer laktat dan normal salin dan perbedaan perubahan yang terjadi antara kedua kelompok cairan pada anak dengan syok.

\section{Metode}

Penelitian uji klinik terbuka yang membandingkan perubahan SID dan $\mathrm{pH}$ pada pemberian RL dan NS. Alokasi subjek penelitian menggunakan randomisasi blok yang dilakukan agar terdapat kesetaraan jumlah subjek yang terdistribusi pada masing-masing kelompok. Randomisasi blok ditentukan dari tabel sekuens dengan enam subjek tiap blok, masingmasing tiga subjek tiap kelompok terapi. Dilakukan consecutive sampling sampai jumlah sampel terpenuhi. Penelitian dilakukan di Unit Perawatan Intensif Anak (UPIA) RSUP Mohammad Hoesin Palembang pada bulan Juli 2014 sampai Maret 2015. Kriteria inklusi adalah anak usia 1 bulan sampai 14 tahun yang datang dengan syok kemudian mendapat resusitasi cairan RL atau NS 20-40 cc/kgbb intravena dan diperiksa analisis gas darah dan elektrolitnya. Kriteria eksklusi adalah subjek yang tidak berhasil dianalisis gas darah (AGD) dan elektrolit awal atau mendapat cairan resusitasi menggunakan koloid. Subjek yang meninggal atau mendapat cairan koreksi elektrolit sebelum pemeriksaan kedua dinyatakan drop out. Pemeriksaan AGD dan elektrolit yang kedua dilakukan enam jam setelah dimulainya resusitasi cairan. Penelitian telah mendapatkan sertifikasi etik dari Unit Bioetika dan Humaniora FK UNSRI Palembang. Seluruh data dianalisis dengan SPSS 22.0. 


\section{Hasil}

Didapatkan subjek berjumlah 47 anak, 24 pada kelompok RL dan 23 kelompok NS. Terdapat satu subjek meninggal pada kelompok RL dan dua mendapatkan koreksi elektrolit pada kelompok NS yang dikeluarkan dari penelitian sehingga terdapat drop out $6,8 \%$. Seluruh subjek yang dapat dianalisis berjumlah 44, terdiri atas $20(45,2 \%)$ anak laki-laki dan $24(54,8 \%)$ perempuan dengan median usia 37 bulan (2-168) bulan. Selain jenis kelamin, tidak terdapat perbedaan bermakna dalam karakteristik umum subjek kedua kelompok, termasuk rerata jumlah cairan yang didapat. Data laboratorium awal juga tidak menunjukkan adanya perbedaan bermakna pada kedua kelompok (Tabel 1).

Subjek penelitian yang mendapatkan cairan RL terdapat 19 subjek dengan nilai SID awal di bawah normal, tiga normal, dan satu di atas normal. Subjek penelitian yang mendapatkan cairan NS terdapat 16 subjek dengan nilai SID di bawah normal, dua normal, dan tiga di atas normal.

Pada pemberian cairan RL tidak didapatkan perbedaan bermakna dalam komposisi elektrolit, perbedaan ion kuat $(S I D)$, dan tingkat keasaman plasma $(\mathrm{pH})$ sebelum dan sesudah pemberian cairan. Rerata kadar SID sebelum pemberian cairan adalah $32,96 \pm 5,26 \mathrm{mEq} / \mathrm{L}$ kemudian turun setelah pemberian cairan menjadi $32,32 \pm 6,34 \mathrm{mEq} / \mathrm{L}(\mathrm{p}=0,089)$ dan median $\mathrm{pH}$ meningkat dari 7,40 menjadi 7,42 sesudah pemberian cairan $(\mathrm{p}=0,346)$. Komposisi elektrolit yang ditemukan tidak berbeda bermakna sebelum dan sesudah pemberian RL (Tabel 2).

Pada pemberian NS, rerata $S I D$ mengalami penurunan yang lebih besar $(34,44 \pm 8,1) \mathrm{mEq} / \mathrm{L}$ menjadi $(32,46 \pm 8,2) \mathrm{mEq} / \mathrm{L}$, tetapi perubahan tersebut secara statistik tidak bermakna $(p=0,354)$. Tingkat keasaman $(\mathrm{pH})$ pada pemberian NS tidak menunjukkan perbedaan bermakna sebelum dan sesudah pemberian cairan $(\mathrm{p}=0,434)$. Berbeda dengan RL, pemberian NS didapatkan penurunan kadar kalium yang bermakna dengan rerata sebelum pemberian $4,32 \pm 1,05 \mathrm{mEq} / \mathrm{L}$ menjadi $3,73 \pm 1,06 \mathrm{mEq} / \mathrm{L}(\mathrm{p}=0,031)$. Penurunan kalium yang terjadi maksimum $3,4 \mathrm{mEq} / \mathrm{L}$ yaitu pada seorang subjek penelitian dengan kadar kalium awal $6,7 \mathrm{mEq} / \mathrm{L}$ dan setelah dilakukan resusitasi cairan menggunakan NS menjadi $3,3 \mathrm{mEq} / \mathrm{L}$.

Dilakukan analisis perbandingan selisih komponen plasma setelah diberikan kedua jenis cairan. Pada kedua kelompok, SID mengalami penurunan dengan subjek yang mendapatkan resusitasi cairan NS menunjukkan rerata selisih penurunan yang lebih besar dibanding $\mathrm{RL}$ $(-1,97 \pm 3,18$ berbanding $-1,22 \pm 3,18) \mathrm{mEq} / \mathrm{L}$, tetapi dari analisis statistik dengan menggunakan uji Mann Whitney U tidak menunjukkan perbedaan bermakna $(\mathrm{p}=0,177)$.

Selisih tingkat keasaman $(\mathrm{pH})$ plasma pada pemberian RL dan NS keduanya mengalami peningkatan, tetapi tidak menunjukkan perbedaan bermakna. Perubahan pH kelompok RL 0,013 $\pm 0,088$ dan NS $0,032 \pm 0,11(\mathrm{p}=0,534)$. Perubahan komposisi elektrolit dan komponen plasma lainnya juga tidak berbeda bermakna (Tabel 3).

\section{Pembahasan}

Kedua kelompok terapi memiliki karakteristik umum yang tidak berbeda bermakna kecuali pada jenis kelamin, tetapi dapat dianggap tidak menjadi perancu karena tidak diketahui terdapat perbedaan SID antara laki-laki dan perempuan. Parameter fisiologis, laboratorium, status asam basa, serta kebutuhan cairan resusitasi juga tidak berbeda bermakna sehingga kami menyimpulkan kedua kelompok memiliki tingkat keparahan penyakit yang sebanding.

Pada perbandingan hasil sebelum dan sesudah pemberian cairan didapatkan perubahan signifikan pada kadar kalium kelompok NS, tetapi tidak pada kelompok RL. Kadar kalium kedua kelompok mengalami penurunan, tetapi pada kelompok yang diresusitasi dengan cairan NS mengalami penurunan lebih besar. Dengan adanya mekanisme pengenceran (dilution) yang terjadi pada pemberian cairan dalam jumlah besar, kadar komponen plasma akan turun termasuk kalium. Cairan NS tidak mengandung kalium sehingga pemberiannya akan menyebabkan penurunan kadar kalium yang lebih besar dibandingkan pada pemberian RL yang mengandung kalium. Sementara kadar natrium dan klorida ditemukan meningkat lebih banyak pada kelompok NS. Temuan tersebut dapat dijelaskan karena kadar natrium dan klorida pada RL lebih kecil (130 dan 109) mEq/L dibanding NS (154 dan 154) $\mathrm{mEq} / \mathrm{L}$. Meskipun demikian, pada analisis statistik keduanya tidak ditunjukkan perbedaan yang bermakna. Pada penelitian oleh Dyah dan Latief ${ }^{10}$ juga didapatkan penurunan kalium dan penambahan klorida lebih besar pada NS, sedangkan natrium tidak berubah bermakna. 
Tabel 1. Karakteristik umum masing-masing kelompok $(\mathrm{n}=44)$

\begin{tabular}{|c|c|c|c|}
\hline Variabel & $\begin{array}{l}\text { Ringer laktat } \\
\quad(\mathrm{n}=23)\end{array}$ & $\begin{array}{l}\text { Normal salin } \\
\quad(\mathrm{n}=21)\end{array}$ & $\mathrm{p}$ \\
\hline Jenis kelamin (\%) & & & $0,032^{* *}$ \\
\hline Laki laki & $9(20,5)$ & $15(34,1)$ & \\
\hline Perempuan & $14(31,8)$ & $6(13,6)$ & \\
\hline Status gizi (\%) & & & $0,452^{* *}$ \\
\hline Baik & $15(34,1)$ & $11(25)$ & \\
\hline Kurang & $8(18,2)$ & $9(20,5)$ & \\
\hline Buruk & 0 & $1(2,2)$ & \\
\hline Umur (bulan) & $54,26 \pm 44,49$ & $55,71 \pm 61,83$ & $0,93^{*}$ \\
\hline \multicolumn{4}{|l|}{ Variabel fisiologis } \\
\hline Tekanan darah (sistolik), (\%) & & & $0,418^{* *}$ \\
\hline Tidak terukur & $5(11,4)$ & $3(6,8)$ & \\
\hline Hipotensi & $3(6,8)$ & $6(13,6)$ & \\
\hline Normal & $15(34)$ & $12(27,3)$ & \\
\hline Nadi (kali/menit), (\%) & & & $0,57^{* *}$ \\
\hline Normal & $9(20,5)$ & $10(22,7)$ & \\
\hline Meningkat (takikardi) & $14(31,8)$ & $11(25)$ & \\
\hline Menurun (bradikardi) & 0 & 0 & \\
\hline Respirasi (kali/menit), (\%) & & & $0,168^{* *}$ \\
\hline Normal & $8(18,2)$ & $11(25)$ & \\
\hline Meningkat (takipneu) & $12(27,3)$ & $10(22,7)$ & \\
\hline Menurun (bradipneu/apneu) & $3(6,8)$ & 0 & \\
\hline Suhu $\left({ }^{\circ} \mathrm{C}\right)$ & $37,05 \pm 0,78$ & $37,52 \pm 0,99$ & $0,087^{*}$ \\
\hline \multicolumn{4}{|l|}{ Jumlah cairan } \\
\hline Cairan total $(\mathrm{ml} / \mathrm{kgbb})$ & $49,45 \pm 17,01$ & $49,72 \pm 20,84$ & $0,963^{*}$ \\
\hline Cairan resusitasi (n, ml/kgbb) & & & $0,839^{* *}$ \\
\hline 20 & 8 & 9 & \\
\hline 30 & 3 & 2 & \\
\hline 40 & 12 & 10 & \\
\hline Hemoglobin (g/dL) & $12,27 \pm 3,45$ & $10,81 \pm 2,68$ & $0,129^{*}$ \\
\hline Hematokrit (\%) & $35,26 \pm 10,03$ & $31,81 \pm 7,32$ & $0,203^{*}$ \\
\hline Leukosit $(/ \mu \mathrm{L})$ & $16247,83 \pm 10269,94$ & $20366,67 \pm 15515$ & $0,301^{*}$ \\
\hline Trombosit $(/ \mu \mathrm{L})$ & $165130,43 \pm 187402,89$ & $269650 \pm 222649,42$ & $0,102^{*}$ \\
\hline Gula darah sewaktu (mg/dL) & $101,48 \pm 21,358$ & $123,76 \pm 94,90$ & $0,304^{*}$ \\
\hline Ureum $(\mathrm{mg} / \mathrm{dL})$ & $56,0 \pm 47,16$ & $55,43 \pm 48,24$ & $0,969^{*}$ \\
\hline Kreatinin $(\mathrm{mg} / \mathrm{dL})$ & $0,74 \pm 0,71$ & $0,75 \pm 0,74$ & $0,978^{*}$ \\
\hline SGOT (U/L) & $399,91 \pm 554,01$ & $318,88 \pm 876,08$ & $0,722^{*}$ \\
\hline SGPT (U/L) & $223,87 \pm 451,34$ & $97,41 \pm 182,02$ & $0,283^{*}$ \\
\hline $\operatorname{Albumin}(\mathrm{g} / \mathrm{dL})$ & $2,94 \pm 0,89$ & $3,25 \pm 0,98$ & $0,289^{*}$ \\
\hline Natrium (mEq/L) & $135,7 \pm 8,01$ & $140,33 \pm 9,59$ & $0,226^{*}$ \\
\hline Kalium (mEq/L) & $4,66 \pm 1,46$ & $4,32 \pm 1,05$ & $0,352^{*}$ \\
\hline Kalsium (mEq/L) & $0,403 \pm 0,04$ & $0,39 \pm 0,053$ & $0,665^{*}$ \\
\hline Klorida (mEq/L) & $107,8 \pm 8,03$ & $110,6 \pm 13,2$ & $0,427^{*}$ \\
\hline $\operatorname{SID}(\mathrm{mEq} / \mathrm{L})$ & $32,96 \pm 5,26$ & $34,44 \pm 8,1$ & $0,822^{*}$ \\
\hline $\mathrm{pH}$ & $7,40(6,98 \mathrm{~s} / \mathrm{d} 7,571)$ & $7,29(7,037 \mathrm{~s} / \mathrm{d} 7,602)$ & $0,288^{* * *}$ \\
\hline $\mathrm{pCO} 2(\mathrm{mmHg})$ & $37,08 \pm 15,74$ & $37,7 \pm 15,76$ & $0,869^{*}$ \\
\hline $\mathrm{pO} 2(\mathrm{mmHg})$ & $109,35 \pm 73,57$ & $107,14 \pm 83,89$ & $0,930^{*}$ \\
\hline $\mathrm{HCO} 3(\mathrm{mmol} / \mathrm{L})$ & $23,2(5,3 \mathrm{~s} / \mathrm{d} 30,2)$ & $20,1(5,5$ s/d 5,4$)$ & $0,753^{* * *}$ \\
\hline Base excess $(\mathrm{mmol} / \mathrm{L})$ & $-3,99 \pm 7,99$ & $-5,05 \pm 14,4$ & $0,744^{*}$ \\
\hline
\end{tabular}

Nilai signifikan bila $\mathrm{p}<0,05$; $^{*}$ uji t tidak berpasangan; ${ }^{* *}$ uji kai kuadrat; ${ }^{* * *}$ Uji Mann Whitney U 
Tabel 2. Perbandingan SID dan $\mathrm{pH}$ sebelum dan sesudah pemberian cairan RL dan NS

\begin{tabular}{|c|c|c|c|c|c|c|}
\hline \multirow[b]{2}{*}{ Variabel } & \multicolumn{3}{|c|}{$\begin{array}{l}\text { Ringer laktat } \\
\mathrm{n}=23\end{array}$} & \multicolumn{3}{|c|}{$\begin{array}{c}\text { Normal salin } \\
\mathrm{n}=21\end{array}$} \\
\hline & $\begin{array}{c}\text { Sebelum } \\
\text { Rerata } \pm \text { SD / } \\
\text { Median } \\
\text { (min s/d max) }\end{array}$ & $\begin{array}{c}\text { Sesudah } \\
\text { Rerata } \pm \text { SD / } \\
\text { Median } \\
\text { (min s/d max) }\end{array}$ & Nilai p & $\begin{array}{c}\text { Sebelum } \\
\text { Rerata } \pm \text { SD / } \\
\text { Median } \\
\text { (min s/d max) }\end{array}$ & $\begin{array}{c}\text { Sesudah } \\
\text { Rerata } \pm \text { SD / } \\
\text { Median } \\
\text { (min s/d max) }\end{array}$ & Nilai $p$ \\
\hline Natrium (mEq/L) & $135,7 \pm 8,01$ & $135,85 \pm 6,86$ & $0,696^{*}$ & $140,33 \pm 9,59$ & $141,93 \pm 8,81$ & $0,162^{*}$ \\
\hline Kalium (mEq/L) & $4,66 \pm 1,46$ & $4,38 \pm 1,48$ & $0,061^{*}$ & $4,32 \pm 1,05$ & $3,73 \pm 1,06$ & $0,031^{*}$ \\
\hline Kalsium $(\mathrm{mEq} / \mathrm{L})$ & $0,403 \pm 0,04$ & $0,386 \pm 0,044$ & $0,07^{*}$ & $0,39 \pm 0,053$ & $0,402 \pm 0,066$ & $0,569^{*}$ \\
\hline Klorida (mEq/L) & $107,8 \pm 8,03$ & $108 \pm 7,69$ & $0,129^{*}$ & $110,6 \pm 13,2$ & $113,6 \pm 11,78$ & $0,065^{*}$ \\
\hline $\operatorname{SID}(\mathrm{mEq} / \mathrm{L})$ & $32,96 \pm 5,26$ & $32,32 \pm 6,34$ & $0,089^{*}$ & $34,44 \pm 8,1$ & $32,46 \pm 7,24$ & $0,354^{*}$ \\
\hline $\mathrm{pH}$ & $\begin{array}{c}7,40 \\
(6,98 \text { s/d 7,571) }\end{array}$ & $\begin{array}{c}7,42 \\
(6,906 \text { s/d 7,518) }\end{array}$ & $0,346^{* *}$ & $\begin{array}{c}7,29 \\
(7,037 \text { s/d 7,602) }\end{array}$ & $\begin{array}{c}7,345 \\
(7,067 \text { s/d 7,501) }\end{array}$ & $0,434^{* *}$ \\
\hline $\mathrm{pCO}_{2}(\mathrm{mmHg})$ & $37,08 \pm 15,74$ & $34,68 \pm 9,44$ & $0,51^{*}$ & $37,7 \pm 15,76$ & $41,8 \pm 22,8$ & $0,214^{*}$ \\
\hline $\mathrm{pO}_{2}(\mathrm{mmHg})$ & $109,35 \pm 73,57$ & $96,99 \pm 66,96$ & $0,517^{*}$ & $107,14 \pm 83,89$ & $150,33 \pm 101,07$ & $0,138^{*}$ \\
\hline $\mathrm{HCO}_{3}(\mathrm{mmol} / \mathrm{l})$ & $\begin{array}{c}23,2 \\
(5,3 \mathrm{~s} / \mathrm{d} 30,2)\end{array}$ & $\begin{array}{c}22,25 \\
(9,2 \mathrm{~s} / \mathrm{d} 30,1)\end{array}$ & $0,543^{* *}$ & $21,26 \pm 12,67$ & $22,58 \pm 11,38$ & $0,184^{*}$ \\
\hline $\mathrm{BE}(\mathrm{mmol} / \mathrm{l})$ & $-3,99 \pm 7,99$ & $-2,6 \pm 8,84$ & $0,109^{*}$ & $-5,05 \pm 14,4$ & $-3,29 \pm 8,84$ & $0,878^{*}$ \\
\hline Albumin (g/dl) & $3,01 \pm 0,92$ & $2,84 \pm 0,81$ & $0,129^{*}$ & $3,11 \pm 1,01$ & $3,08 \pm 0,82$ & $0,634^{*}$ \\
\hline $\mathrm{AG}(\mathrm{mEq} / \mathrm{L})$ & $11,81 \pm 7,48$ & $10,88 \pm 8,5$ & $0,562^{*}$ & $13,59 \pm 7,79$ & $11,43 \pm 6,05$ & $0,087^{*}$ \\
\hline $\mathrm{CAG}(\mathrm{mEq} / \mathrm{L})$ & $21,66 \pm 7,03$ & $21,19 \pm 8,46$ & $0,753^{*}$ & $23,21 \pm 7,75$ & $21,94 \pm 6,06$ & $0,383^{*}$ \\
\hline
\end{tabular}

Tabel 3. Perbandingan selisih SID dan $\mathrm{pH}$

\begin{tabular}{|c|c|c|c|}
\hline Variabel $(\Delta)$ & $\begin{array}{c}\text { Ringer laktat }(\mathrm{n}=23) \\
\text { Rerata } \pm \text { SD } \\
\text { Median (min s/d max })\end{array}$ & $\begin{array}{l}\text { Normal salin }(\mathrm{n}=21) \\
\text { Rerata } \pm \text { SD } \\
\text { Median (min s/d max })\end{array}$ & Nilai $\mathrm{p}$ \\
\hline Natrium (mEq/L) & $0,261 \pm 3,16$ & $1,43 \pm 4,51$ & $0,323^{*}$ \\
\hline Kalium (mEq/L) & $-0,304 \pm 0,75$ & $-0,52 \pm 1,12$ & $0,455^{*}$ \\
\hline Kalsium $(\mathrm{mEq} / \mathrm{L})$ & $-0,015(-0,11 \mathrm{~s} / \mathrm{d} 0,02)$ & $0,007(-0,11 \mathrm{~s} / \mathrm{d} 0,16)$ & $0,091^{* *}$ \\
\hline Klorida (mEq/L) & $0,5(-4 \mathrm{~s} / \mathrm{d} 10)$ & $2.33(-4 \mathrm{~s} / \mathrm{d} 25)$ & $0,696^{* *}$ \\
\hline $\operatorname{SID}(\mathrm{mEq} / \mathrm{L})$ & $-1,22(-8,24 \mathrm{~s} / \mathrm{d} 6,21)$ & $-1,97(-24,49 \mathrm{~s} / \mathrm{d} 5,37)$ & $0,177^{* *}$ \\
\hline $\mathrm{pH}$ & $0,013 \pm 0,088$ & $0,032 \pm 0,11$ & $0,534^{*}$ \\
\hline $\mathrm{pCO}_{2}(\mathrm{mmHg})$ & $-0,41(-44,5$ s/d 23,9) & $4,07(-40,1$ s/d 37,1) & $0,226^{* *}$ \\
\hline $\mathrm{pO}_{2}(\mathrm{mmHg})$ & $-9,26 \pm 67,41$ & $30,9 \pm 91,76$ & $0,103^{*}$ \\
\hline $\mathrm{HCO}_{3}(\mathrm{mmol} / \mathrm{L})$ & $0,53 \pm 4,29$ & $1,71 \pm 5,69$ & $0,441^{*}$ \\
\hline $\mathrm{BE}(\mathrm{mmol} / \mathrm{L})$ & $1,86 \pm 5,34$ & $-0,305 \pm 9,84$ & $0,364^{*}$ \\
\hline Albumin (g/dL) & $-0,16(-1,7 \mathrm{~s} / \mathrm{d} 0,5)$ & $0,043(-1,3 \mathrm{~s} / \mathrm{d} 0,7)$ & $0,218^{* *}$ \\
\hline
\end{tabular}

Signifikan bila $\mathrm{p}<0,05$; *uji t tidak berpasangan; ${ }^{* *}$ uji Mann Whitney $\mathrm{U}$

Berdasarkan konsep asam basa Stewart, pemberian cairan dalam jumlah besar akan menyebabkan terjadinya penurunan SID akibat perubahan elektrolit yang terkandung di dalamnya. Penurunan SID juga terjadi karena pengenceran (asidosis dilusi) sehingga terjadi asidosis metabolik. 5 Pemberian NS dalam volume besar dapat menyebabkan asidosis metabolik dengan meningkatkan konsentrasi relatif klorida terhadap natrium plasma dengan hasil akhir penurunan SID dan pH. Cairan NS juga lebih hipertonik dibandingkan RL sehingga dapat menarik cairan intravaskular menjadi lebih banyak. ${ }^{6}$ Asidosis hiperkloremik yang diprediksi akan terjadi pada pemberian NS tidak terlihat pada penelitian kami. Berbeda dengan laporan 
penelitian sebelumnya oleh Dyah ${ }^{10}$ yang menunjukkan perubahan selisih konsentrasi klorida. Reid $\mathrm{dkk}^{12}$ melaporkan bahwa pemberian bolus intravena cairan NS dan RL sebanyak 2 liter pada sembilan orang dewasa menghasilkan perbedaan yang bermakna dan terjadi hiperkloremia enam jam setelah pemberian NS, sedangkan hal serupa tidak ditemukan pada pemberian RL.

Cairan RL dan NS masing-masing mengandung nilai $S I D$. Pemberiannya akan menyebabkan perubahan komponen kation dan anion kuat dalam plasma yang selanjutnya akan memengaruhi SID plasma. ${ }^{6}$ Kami mendapatkan penurunan SID pada kedua jenis cairan, tetapi pada pemberian cairan RL terjadi penurunan SID yang lebih kecil dibandingkan NS. Ringer laktat mengandung SID $28 \mathrm{mEq} / \mathrm{L}$, sedangkan NS mengandung SID $0 \mathrm{mEq} / \mathrm{L}$. Pemberian kedua cairan ini dapat menyebabkan penurunan SID melalui mekanisme pengenceran. ${ }^{5}$ Pemberian RL diperkirakan akan menghasilkan nilai SID yang lebih mendekati plasma karena sejak awal cairan RL telah mengandung SID sehingga penurunan yang terjadi tidak jauh dari normal. Sementara pada NS dengan SID nol akan menyebabkan penurunan SID plasma lebih besar sehingga berisiko menyebabkan asidosis. Kami tidak mendapatkan perbedaan perubahan SID dan $\mathrm{pH}$ pada pemberian kedua cairan. Kemungkinan pemberian cairan 20 sampai $40 \mathrm{ml} / \mathrm{kgbb}$ belum cukup untuk menyebabkan perbedaan perubahan SID.

Hasil penelitian kami berbeda dengan penelitian Dyah dan Latief ${ }^{10}$ yang menunjukkan adanya perubahan SID pada pemberian NS $20 \mathrm{ml} / \mathrm{kgbb}$. Namun begitu, $\mathrm{pH}$ hasil penelitian tersebut menunjukkan tidak terjadi perubahan sama seperti penelitian ini. Penelitian Schingraber $\mathrm{dkk}^{13}$ melaporkan pemberian NS $30 \mathrm{ml} / \mathrm{kgbb} / \mathrm{jam}$ pada pasien yang dilakukan operasi dengan total cairan $6000 \mathrm{ml}$ menimbulkan asidosis hiperkloremia dan penurunan $\mathrm{pH}$, peningkatan level klorida plasma, dan penurunan SID. Penelitian Skelett $\mathrm{dkk}^{14}$ melaporkan bahwa pada pemberian NS terhadap syok septik $40 \mathrm{ml} / \mathrm{kgbb}$ terjadi peningkatan klorida plasma dan asidosis hiperkloremia karena penurunan SID, tetapi tidak terdapat perubahan kadar laktat anion yang tidak terukur (unmeasured anion).

Perubahan SID yang terjadi pada pemberian kedua cairan tidak berbeda, begitu juga perubahan $\mathrm{pH}$ plasma. Perubahan $\mathrm{pH}$ kedua cairan ini, baik RL maupun NS, sedikit mengalami peningkatan pada pemberian RL yang lebih kecil dibandingkan NS. Hal tersebut sesuai dengan laporan penelitian sebelumnya oleh Dyah dan Latief ${ }^{10}$ yang menunjukkan bahwa $\mathrm{pH}$ tidak mengalami perubahan antara RL dan NS.

Terdapat beberapa kemungkinan penyebab temuan perubahan $\mathrm{pH}$ tidak bermakna. Pertama, kondisi keseimbangan asam basa plasma tidak hanya dipengaruhi oleh SID yang merupakan komponen metabolik, tetapi juga oleh faktor lain, komponen respiratorik dalam hal ini adalah $\mathrm{pCO}_{2}$. Pada kondisi kritis maupun karena pemberian cairan intravena, kemungkinan yang terjadi pada keadaan ketidakseimbangan asam basa plasma adalah terjadinya suatu mekanisme kompensasi dari tubuh, baik dalam keadaan asidosis maupun alkalosis, yang berusaha mempertahankan $\mathrm{pH}$ plasma dalam rentang normal $(7,35-7,45)$. Kompensasi yang terjadi dapat merupakan kompensasi yang komplit ( $\mathrm{pH}$ kembali normal) dan kompensasi parsial $(\mathrm{pH}$ masih di luar nilai normal, tetapi dalam proses menuju normal)..$^{15}$ Kedua, cairan resusitasi yang diberikan dengan volume (20-40) $\mathrm{ml} / \mathrm{kgbb}$ belum dapat menyebabkan perbedaan pada komposisi elektrolit, SID, maupun $\mathrm{pH}$ pada kedua kelompok. Hal tersebut karena mekanisme tubuh sebagai fungsi yang kompleks menyebabkan interaksi sistem fisiologis berusaha mempertahankan homeostasis terhadap perlakuan dari luar. ${ }^{11}$

Keterbatasan penelitian kami adalah analisis terhadap derajat keparahan penyakit subjek penelitian yang mungkin mempunyai pengaruh tertentu terhadap sistem homeostasis tubuh tidak dilakukan. Kami juga tidak melakukan analisis SID dan $\mathrm{pH}$ secara berkala. Penelitian ini tidak mengikutkan penderita yang membutuhkan pemberian cairan melebihi $40 \mathrm{ml} /$ kgbb yang sesuai standar tata laksana UPIA juga harus mendapatkan cairan koloid.

\section{Kesimpulan}

Resusitasi cairan dengan RL dan NS memberikan efek perubahan SID dan $\mathrm{pH}$ yang tidak berbeda pada kasus syok anak di UPIA. Cairan RL maupun NS masih dapat dipergunakan sebagai cairan resusitasi dengan volume $20-40 \mathrm{ml} / \mathrm{kgbb}$ seperti pada penelitian ini. Diperlukan penelitian lanjutan dengan subjek penelitian yang lebih banyak dan waktu yang lebih lama, serta dengan evaluasi perubahan komposisi cairan plasma secara berkala. 


\section{Daftar pustaka}

1. Myburg JA, Mythen MG. Rescucitation fluids. Critical Care Medicine. N Engl J Med 2013;369:1243-51.

2. Boluyt N, Casper WB, Albert PB, Kok JH, Offringa M. Fluid resuscitation in neonatal and pediatric hypovolemic shock: a Dutch Pediatric Society evidence-based clinical practice guideline. Intensive Care Med 2006;32:9951003.

3. Wheeler DS, Rajit KB. Pediatric shock : an overview. Open Pediatr Med J 2013;7:2-9.

4. Darwis D, Munajat Y, Nur MB, Madjid SA, Siregar P, Aniwidyaningsih W, dkk. Gangguan keseimbangan air, elektrolit dan asam basa. Edisi kedua. Jakarta: Balai Penerbit FKUI;2010.

5. Morgan TJ. The meaning of acid-base abnormalities in the intensive care unit: Part III - effects of fluid administration. Crit Care 2005;9:204-11.

6. Kellum JA. Fluid rescucitation and hyperchloremic acidosis in experimental sepsis : improved short term survival and acid base balance with hextend compared with saline. Crit Care Med 2002;30:300-5.

7. Fisher JD, Nelson DG, Beyersdorf H, Satkowiak LJ. Clinical spectrum of shock in the pediatric emergency department. Pediatr Emerg Care 2010;26:622-5.

8. Martin SG. An update on intravenous fluid. Medscape Pediatrics. 19 April 2005. Diakses 6
Maret 2015. Didapat dari: http://www.medscape.org/ viewarticle/503138.

9. Zander R. Fluid management. Edisi kedua. Meslungen: Bibliomed Medizinische Verlagsgesellschaft; 2009.

10. Dyah T, Latief A. Comparison of acid base balance change in hypovolemic shock with $0,9 \%$ normal saline therapy and ringer's lactate. A controlled randomized clinical test. Folia Med Indones 2009;45:1-5.

11. Handy JM, Soni M. Physiological effects of hyperchloremia and acidosis. Brit J Anaesth 2008;101:141-50.

12. Reid F, Lobo DN, William RN, Rowlands BJ, Allison SP. (Ab) normal saline and physiological Hartmann's solution : a randomized double blind cross over study. Clin Sci (Lond) 2003;104:17-24.

13. Scheingraber S, Rehm M, Sehmisch C, Finsterer $\mathrm{U}$. Rapid saline infusion produces hyperchloremic acidosis in patients undergoing gynecologic surgery. Anesthesiology 1999;90:1265-70.

14. Skellett S, Mayer A, Durward A, Tibby SM, Murdoch IA. Chasing the base deficit : hyperchloraemic acidosis following $0.9 \%$ saline fluid rescusitation. Arch Dis Child 2000;83:514-6.

15. Lewis JL. Acid-base regulation and disorders. The Merck Manual Professional Version. Diakses 6 Maret 2015. Didapat dari: http://www.merckmanuals.com/professional/ endocrine-and-metabolic-disorders/acid-base-regulation-anddisorders/acid-base-disorders. 